\title{
Övergrepp mot äldre i två perspektiv
}

\author{
HÅKAN JÖNSON
}

\begin{abstract}
Hur ska man förstå problemet övergrepp mot äldre? Vilka är orsakerna, vemär typiskt sett offret och vad ska man göra åt problemet? I artikeln diskuteras två perspektiv som med olika utgångspunkter givit svar på dessa frågor.
\end{abstract}

\section{Introduktion}

Internationellt har övergrepp mot äldre ägnats vetenskaplig uppmärksamhet sedan slutet av 1970-talet (McCreadie 1993). Forskare och praktiker inom vårdområdet har sedan dess utvecklat ett dominerande vård- och välfärdsparadigm om övergrepp mot äldre (Brogden \& Nijhar 2000). Framför allt har omvårdsnadsprofessionernas praktiker och forskare haft stor betydelse (Wolf 1996). Internationellt har en andra generation forskare och aktivister från slutet av 1980-talet använt socialkonstruktivistiska och feministiska analyser för att bland annat kritisera inplaceringen av övergrepp mot äldre inom vårdområdet (Callahan 1988; Baumann 1989; Whittaker 1997; Brogden \& Nijhar 2000). Sedan

Håkan Jönson är universitetslektor vid Malmö högskola och innehar för närvarande en FAS-finansierad forskarassistenttjänst vid Tema Äldre och aildrande, Linköpings universitet. mitten av 1980-talet har nordiska forskare undersökt förekomsten av övergrepp mot äldre i hemmet och utvecklat modeller för upptäckt och intervention (Tornstam 1989; Hydle \& Johns 1993; Saveman 1994; Perttu 1996). Ett feministiskt perspektiv på övergrepp mot äldre har framträtt i Sverige omkring millennieskiftet (Eriksson 2001; Johansson 2002). ${ }^{1}$

1 Det förekommer andra beskrivningar av problemets utveckling. Rosalie Wolf (1996, s. xi) skriver exempelvis: "Originally, the abuse and neglect of older persons was viewed in the context of services, next, it was framed as an issue of aging. Next, it was viewed as an issue of family violence, and, later, crime." Vissa forskare har också försökt lansera ett kriminologiskt perspektiv som fokuserar själva (den brottsliga) handlingen (Brogden \& Nijhar 2000). Det perspektivet står som en kritik mot en dominerande klinisk/medicinsk inriktning, men tycks möjligt att förena med ett feministiskt perspektiv. 
Övergrepp mot äldre i familjen är givetvis inget nytt fenomen, problemets omfattning i Sverige under 1700- och 1800-talet indikeras av förekomsten av särskilda lagar som introducerades för att skydda äldre från andra familjemedlemmars aggression (Odén 1991). Övergrepp inom familjen och på institutioner behandlas vanligen som två separata problem. Medan övergrepp i familjen försvann från den offentliga dagordningen under slutet av 1800-talet, har vanvård och missförhållanden på institutioner återkommande blivit föremål för allmän debatt (Lo-Johansson 1952; Jönson 2002). Inom forskningen om övergrepp har den formella äldreomsorgen ägnats mindre uppmärksamhet (Saveman et al. 1999).

I den här artikeln ska jag diskutera våld och övergrepp mot äldre som samhällsproblem. Två tolkande perspektiv som lämnat viktiga bidrag för förståelsen av fenomenet kommer att sättas i kritisk betraktelse. Ett kliniskt/medicinskt perspektiv har relaterat övergrepp mot äldre till orsaker och lösningar som är vanliga inom vårdprofessionella praktiker. Ett feministiskt perspektiv har relaterat problemet - uttryckt som vaild mot äldre kvinnor (och män) - till samhällelig ojämlikhet mellan könen och fokuserat äldre kvinnors särskilda sårbarhet. I artikeln kommer jag att visa hur dessa två perspektiv tenderar att göra vissa versioner av problemet särskilt synliga, medan andra tonas ned eller hamnar vid sidan av problemformuleringen. Både särskiljande och gemensamma resonemang kommer att beskrivas. Perspektivens konstruktion av problemet möjliggör också i olika grad spridning och genomslag utanför de arenor där de formulerats. I artikeln kommer denna aspekt dis- kuteras med utgångspunkt i hur perspektiven anknyter till moraliska uppfattningar i olika sammanhang.

I genomgången berörs framför allt övergrepp i hemmet, men också övergrepp som begås av vårdpersonal diskuteras, eftersom de två perspektiven använts för att tolka övergrepp inom informella såväl som formella vårdsituationer.

\section{Perspektivberoendet}

Med ett perspektiv avser jag här ett sammanhållet paket av resonemang och exempel, som används för att "rama in«, karaktärisera och förklara olika fenomen (Jönson 2002). I artikeln undviker jag att använda det snävare och mer specifikt definierade begreppet paradigm eftersom de perspektiv jag identifierar till stora delar utvecklats av professionella aktörer och politiska aktivister inom bestämda sammanhang. Studier av perspektiv är viktiga eftersom de kan ge svar på frågor om varför vissa fenomen ägnas intresse inom olika sammanhang, medan andra förblir ouppmärksammade. Enkelt uttryckt ger perspektiv synlighet åt fenomen som passar inom perspektivet, medan fenomen som riskerar att ställa till oreda negligeras eller förklaras bort. Perspektiv har med andra ord en självbekräftande karaktär.

I genomgången om övergrepp mot äldre kommer jag lyfta fram en tvåsidighet hos perspektiv som beskriver avvikande beteende. Sådana perspektiv förklarar fenomen och gör dem begripliga, men samtidigt tillhandahåller de bakgrundsförväntningar som gör det möjligt för aktörer att rikta anklagelser mot vissa parter, tillskriva aktö- 
rer motiv och ursäkta eller legitimera egna ageranden (jfr Mills 1940; Scott \& Lyman 1968). Perspektiv används alltså som verktyg av sociala aktörer. I artikeln kommer jag att diskutera denna tvåsidighet med hjälp av begreppet moraliska redovisningar ("accounts" på engelska, skrivs fortsättningsvis som redovisningar). Redovisningar är lingvistiska verktyg som sociala aktörer använder för att förklara opassande agerande (Scott \& Lyman 1968). De används när en persons handlande ifrågasätts på något sätt, som en slags förklaring med karaktär av svaromål. Men vi befinner oss, menar Billig (1996) nästan ständigt i ett slags svaromål, eftersom vi själva har kännedom om möjliga invändningar till våra handlingar och resonemang. Därför kan redovisningar betraktas som ett mycket vidsträckt och allmänt fenomen. Det som är avgörande för om man måste redovisa för en handling är om handlingen strider mot omgivningens förväntningar och det är i förhållande till dessa bakgrundsförväntningar som redovisningarna orienterar. Bakgrundsförväntningarna skiftar mellan olika sammanhang, vilket betyder att olika handlingar ifrågasätts och olika redovisningar godtas. Det är enligt min mening här förekomsten och genomslaget av förklarande perspektiv får stor betydelse. Perspektiv byggs delvis upp av redovisningar men tillhandahåller samtidigt bakgrundsförväntningar och riktlinjer för vilka redovisningar som accepteras och vilka som inte accepteras. Det betyder att aktörer som utvecklar olika perspektiv - exempelvis kliniska/medicinska och feministiska - är olika benägna att acceptera eller avvisa olika redovisningar om övergrepp, både allmänt och i enskilda fall.

\section{Några reservationer om perspektiv}

Att sammanställa perspektiv och renodla teman på det sätt som jag gör nedan kan bidra till teoretiska insikter, men samtidigt förenklas resonemang på ett måhända orättvist sätt. Perspektiv är inte så homogena som de framstår i en genomgång av det slag jag genomför. Människor är heller inte perspektivrobotar, utan de sammanfogar resonemang ur olika perspektiv och varierar sina uppfattningar beroende av sammanhang. I analysen beskriver jag exempelvis författare av handledningar om övergrepp mot äldre som företrädare för ett kliniskt/ medicinskt perspektiv, väl medveten om att samma författare i andra sammanhang kan ha producerat arbeten som behandlar strukturella förhållanden (jfr Hydle \& Johns 1993; 1995). Detsamma gäller för en av de rapporter som i min genomgång används för att illustrera det feministiska perspektivet (Eriksson 2001). Jag påstår alltså inte att den rapportens författare använder just detta perspektiv i andra sammanhang för det vet jag inte. I min analys är det rapporten som visar hur ett perspektiv utvecklas.

\section{Det är oklart vad som menas med övergrepp mot äldre}

Möjligheten för olika perspektiv att uppträda ökar om ett fenomen kan definieras på många olika sätt. Det är oklart vad begrepp som "övergrepp mot äldre» och "elder abuse» omfattar (Saveman 1994, s 9-12). I Sverige relaterar begreppet inte till legala bestämmelser, utan har efter internationell förebild utvecklats inom ett vård- 
och välfärdsprofessionellt sammanhang. I likhet med "child abuse" avser "elder abuse" att fånga fenomen som inte synliggörs i allmänna diskussioner om våld och brott mellan vuxna människor. Det speciella förhållande som legitimerar särskilt kunskap om övergrepp mot äldre har att göra med sårbarhet och beroende under ålderdomen - vissa äldre är orediga, det kan vara svårt att skilja mellan skador från olyckor och illegitimt våld som drabbar skröpliga personer, interventioner som involverar skröpliga personer kan vara särskilt komplicerade eftersom de ofta slutar med att offret institutionaliseras etc. Internationellt råder det emellertid oenighet om huruvida enbart övergreppshandlingar som relaterar till vård- och omsorgsrelationer ska inkluderas, eller om övergreppshandlingar mot alla personer över 65 år (ibland 60 år eller liknande) ska räknas(Hugman 1995; Slater 1999). Det är omdebatterat om endast avsiktliga handlingar ska utgöra övergrepp (Hudson 1991). Det är också oklart om övergrepp i första hand ska användas för att diskutera någon slags fortgående missförhållande, eller om också tillfälliga händelser ska räknas. I kliniska sammanhang fokuseras vanligen ihållande fenomen, medan studier som avser att kartlägga prevalens ofta medräknar tillfälliga incidenter. Ytterligare en oklarhet rör om viktimisering med främmande förövare och formella vårdare som besöker hemmet ska räknas som "övergrepp i hemmet", eller om begreppet ska reserveras för de nära relationerna (Tornstam 1989; Pritchard 1993; Jönson 2002).

Definitioner av övergrepp mot äldre kan både inkludera och exkludera försummelser/vanvård, i det senare fallet skrivs de två begreppen ofta samman som "elder abuse \& neglect». Ofta förekommer uppdelningar i fysiska, psykologiska (verbala), sexuella och ekonomiska övergrepp, aktiv och passiv försummelse, samt olika typer av felaktig vård. Vissa definitioner medräknar handlingar som den enskilde utsätter sig själv för (eller inte), det som internationellt benämns "self-abuse» och "self-neglect" (jfr Ansello 1996). Ibland används begrepp som "mistreatment" och "maltreatment", vilka dels vidgar fenomenet men samtidigt ger det en omvårdnadskaraktär. Definitioner av övergrepp är vidare kulturellt beroende, i bemärkelsen att de normer och regler som övergrepp och försummelser bryter emot varierar mellan länder och kulturer. Detta gäller skyldigheter att ta vård om anhöriga, synen på tvångsåtgärder mot gamla i olika sammanhang, förekomst av lagar om särskilda medborgerliga rättigheter för äldre etc.

I studier av prevalens brukar man räkna med att 1-8 procent av den äldre befolkningen utsatts för övergrepp under det senaste året, men med tanke på skillnader i definitioner är det mycket svårt att jämföra olika undersökningar. Ett vanligt men inte entydigt resultat är att kvinnor oftare är utsatta än män, och att karaktären av övergrepp mot män respektive kvinnor ibland skiftar (Brogden \& Nijhar 2000; Kosberg \& Nahmiash 1996).

\section{Tre idealtypiska fall}

Om övergrepp mot äldre $i$ hemmet definieras extensivt blir det uppenbart att problem med mycket olika orsaker och karaktär förts samman. I synnerhet framstår de 
fall där offret s.a.s. är sin egen förövare som aparta. I den internationella forskningen har övergrepp mot äldre relaterats till orsaker som individuell patologi hos förövare såväl som offer, interpersonella orsaker som beroenderelationer och cykler av våld mellan generationer inom familjer, sociala orsaker som fattigdom och avsaknad av stöd hos åldrande familjer och kulturella orsaker som ålderism, sexism och samhällelig acceptans för våld inom familjen (Ansello 1996; Brogden \& Nijhar 2000). I Sverige och Norden har en relativt extensiv definition av övergrepp etablerats (Hydle \& Johns 1993; Saveman 1994). Den spänning en sådan definition bär på blir synlig i tre typfall som ofta lyfts fram för att belysa övergrepps olika orsaker och dynamik (se exempelvis SoS-rapport 1994:1; Saveman \& Hallberg 1994):

- Typfall 1: Övergrepp som beror på en ansträngd vårdrelation. Exemplet här skulle kunna vara en make eller ett vuxet barn som på grund av ansträngningen är hårdhänt eller elak mot en anhörig som han/hon vårdar. Det kan också tänkas att den som vårdas är våldsam eller hotfull i förhållande till den anhörige.

- Typfall 2: Vanlig s.k. kvinnomisshandel som fortgår in $\mathrm{i}$ ålderdomen. Exemplet är den äldre mannen som misshandlar sin hustru, vilket han gjort under många år.

- Typfall 3: Övergrepp som hänger samman med långvariga familjeproblem, sociala eller psykiska problem hos anhöriga, där förövaren ofta står i något slags beroendeförhållande till offret. Exemplet här kan vara ett hemmabo- ende vuxet barn med missbruksproblem, som pressar sin åldrade förälder på pengar.

Dessa typfall och avgränsningarna mellan dem kan i någon mån användas för att visa på betoningar inom det kliniska/medicinska perspektivet respektiverdet feministiska perspektivet.

\section{Det kliniska/medicinska perspektivet}

I internationella genomgångar har det noterats att övergrepp mot äldre konstruerats som ett problem som ska undersökas och lösas av omvårdnadsforskare och välfärdsprofessionella aktörer (Callahan 1988). Problemet har placerats inom ett medicinskt paradigm, där analysen av orsaker fokuserat på förövarens och offrets patologi, eller på brister $\mathrm{i}$ en omvårdnadssituation (Brogden \& Nijhar 2000). I en genomgång av övergreppsforskning menar Eastman (1999) att den medicinska modellens syfte är att förutse, kategorisera, diagnosticera och behandla. Det blir enligt Brogden \& Nijhar (2000, s 16) de vårdprofessionella aktörerna som tar hand om problemet och avgör huruvida andra aktörer, exempelvis rättsväsendet ska involveras: „Welfare and social service agencies constructed a newly perceived problem as their property, to be dealt with by their staff and their procedures." (Brogden \& Nijhar 2000, s. 17) Med det kliniska/medicinska perspektivet har lösningar definierats i termer av sociomedicinska interventioner, stöd, utbildning och ökad välfärd. Ett illustrerande exempel utgör antologin "Abuse, Neglect and 
Exploitation of Older Persons" (Baumhover \& Beall 1996), vars avslutande sektion bär namnet "Some Solutions to the Problem". Sektionens tre bidrag är helt inriktade på kliniska förhållanden, där vårdpersonalens roll ställs i centrum.

I vid bemärkelse har ett kliniskt/medicinskt perspektiv (där omvårdnadsforskare lämnat viktiga bidrag) varit framträdande också i Norden. Det är framför allt till vårdprofessionella av olika slag som information riktats, det är så att säga deras perspektiv forskningen tagit. En spridd lärobok av den norske läkaren Ida Hydle och socialantropologen Sigurd Johns illustrerar perspektivet. Även om Hydle \& Johns (1993) också kritiserar ett medicinskt tänkande och introducerar ett moralisk tolkningsram för upptäckt av övergrepp har deras vokabulär och resonemang ett kliniskt/medicinskt fokus. Deras ansats syftar till att förse vårdpersonal och vårdorganisationer med kunskap och rutiner som gör det möjligt att upptäcka och intervenera i fall av övergrepp. Samma fokus återfinns hos ledande forskare i Sverige och Finland (Saveman 1994; et al. 1998; Perttu 1996). Kunskapsobjekten är patienten som drabbas av övergreppet och behöver klinisk intervention, familjeenheten där övergreppet äger rum och döljs men också kan förändras, samt interventionsenheten, som i första hand består av omvårdnadspersonal, läkare och socialarbetare, men också kan inkludera anhöriga m.fl. i olika allianser.

Genom att visa hur övergrepp mot äldre framträder inom klinisk praktik har perspektivet åskådliggjort problemets komplexa och varierade karaktär. Det kliniska perspektivets metodologi syftar till en för- djupad förståelse av familjens patologiska dynamik, baserad på intervjuer med de inblandade personerna. Målet är intervention. Hydle \& Johns (1993) menar att fokuseringen av fenomenets komplexitet motverkar ett förenklat syndabockstänkande och fördömanden av förövare. Våld inom familjen kan som exempel framstå som den enda utvägen ur ett symbiotiskt förhållande, eller kan reflektera förändrade styrkeförhållanden mellan barn och föräldrar. Övergrepp får därmed karaktären av brott med två offer, eller brott utan förövare.

Eastman (1999) varnar för att det vidare sociala sammanhanget förloras med ett kliniskt fokus. Internationellt har den kliniska inriktningens intresse för orsaker och intervention också anklagats för att hindra en fokusering av själva handlingen, vilket hade varit naturligt om övergrepp i högre grad behandlats som brottslighet (Brogden \& Nijhar 2000). Anklagelser om att omvårdnadsforskare lagt under sig frågan om övergrepp mot äldre i någon slags professionaliseringssträvanden framstår som något orättvisa, med tanke på att den kliniska inriktningen inte precis konkurrerat ut existerande problemformuleringar. I Norden har perspektivet heller inte fătt någon nämnvärd spridning utanför just den vårdprofessionella arenan. Det är snarast så att den kliniska inriktningen - med de brister som påtalats - synliggjort ett problem som tidigare inte ägnades intresse av någon part, i synnerhet inte rättsväsendet. Dessutom tycks den nordiska forskningen skilja sig från exempelvis den brittiska. Medan brittisk forskning om övergrepp inriktats på missförhållanden i omvårdnadsrelationer (typfall 1 ovan) har den nordiska forsk- 
ningen tagit sin utgångspunkt i olika typer av konflikter i familjen och i viss mån också behandlat strukturella förhållanden (Hydle \& Johns 1993; Johns \& Hydle 1995; Saveman 1994).

Det kliniska/medicinska perspektivet beskriver försök att rädda av våldsutsatta åldringar (framför allt kvinnor) genom olika omvårdnadsarrangemang - påfallande ofta institutionalisering (jfr Hydle \& Johns 1993). Vårdsystemet och dess företrädare har flera roller i de berättelser som illustrerar problemet, det agerar som räddare genom interventioner och som medskyldiga i de fall då övergreppen relateras till bristande samhälleligt stöd. Vårdsystemets aktörer ska också informeras och involveras i fungerande system för upptäckt och intervention. Rollbesättningen är synlig i den vittnessansats som Hydle \& Johns använder för att definiera enskilda fall av övergrepp. I sin bok om övergrepp mot äldre i hemmet beskriver Hydle \& Johns svårigheterna att avgöra vad som är ett övergrepp eller inte. Ska man utgå från den drabbades skador när skador kan uppstå på ett legitimt sätt? Hur ska man se på det faktum att inblandade parter ofta uppfattar skeenden helt olika? Hydle \& Johns föreslår en definition som utgår ifrån att moraliskt illegitima kränkningar av någons personliga gränser utgör övergrepp. Hur ska man då avgöra om gränserna kränkts på ett illegitimt sätt? I Hydle \& Johns modell avgörs frågan av ett slags vittne - som likt en informell domare samlar fakta och avgör hur skeendet ska bedömas. Det är en elegant lösning som samtidigt tenderar att lokalisera problemet till det kliniska sammanhanget. I praktiken är vittnet antagligen en ansvarig sjuksköter- ska, läkare eller socialarbetare inom hälsooch sjukvård. Som illustration till svårigheten att dra gränsen mellan omsorgsfull vård och övergrepp berättar Hydle \& Johns om den 87-årige Arthur som kom in på sjukhuset i mycket dåligt skick: "Han låg ihopkrupen i sängen och reagerade bara med fruktan på sköterskornas kontaktförsök. Han var undernärd och uttorkad, hade flera fula sår på kroppen och ett ben som måste amputeras på grund av kallbrand. Sex veckor efter att han blev inlagd dog han på sjukhuset." (s. 57). Artur hade bott med sin vuxne son och man misstänkte genast övergrepp. En läkare med kännedom om familjen invände emellertid att sonen verkade ha haft ovanligt starka känslor av omsorg och plikt mot sin far, trots att fadern blivit allt mer vårdkrävande hade sonen försökt ta hand om honom. I samtal redovisade sonen utan omsvep för hur han vårdade sin fader och denna historia fick "vittnena" att konstatera att den gamle mannens gränser kränkts, men att handlingarna inte varit övergrepp. De hade skett av omsorg och i ett gott syfte, av en person som inte förmådde bättre och dessutom inte fick adekvat stöd av samhället: "Vi bedömde fortfarande Arthur som ett skadat offer, men vår bild av sonen ändrade sig. Vi uppfattade fortfarande sonen som utövare av kontroll, men kontroll i form av omsorg, inte våld. Därmed bedömde vi inte detta som ett fall av övergrepp. I egenskap av vittnen, ändrade vi uppfattning om legitimiteten." (s 59, kursiv i original). Fallet avslöjade enligt Hydle \& Johns svagheter i primärvården och särskilt kritiserades de sjuksköterskor som känt till situationen utan att intervenera. 
Brogden \& Nijhar (2000) menar att ett tänkande som fokuserar patologi underbetonar rationella aspekter av övergrepp. Förövare bör enligt Brogden \& Nijhar betraktas som rationella och övergrepp bör föras in $\mathrm{i}$ ett »kriminologiskt» perspektiv. En förebild för ett sådant tänkande finns i problemet mäns våld mot kvinnor, som efter kvinnorörelsens kamp i högre grad kommit att betraktas som "riktiga» brott. Även om det kan ifrågasättas om äldre offer för övergrepp skulle få en bättre situation om exempelvis polis, åklagare och domstolar fick ett större ansvar, visar den kriminologiska kritiken på en möjlig svaghet hos det kliniska perspektivet. Om förövare är rationella och kompetenta är det sannolikt att de ursäktar och rättfärdigar sina normbrytande handlingar med hänvisning till förhållanden som resonerar med omgivningens bakgrundsförväntningar (Scott \& Lyman 1968). En person som använder ett rättfärdigande accepterar ansvar för en handling, men förnekar att handlingen är förkastlig (hänvisningar till självförsvar är ett exempel). En person som använder en ursäkt accepterar att en handling är förkastlig, men förnekar fullt ansvar för sitt agerande (hänvisningar till påverkan från externa faktorer är ett exempel). I praktiken används ofta båda teknikerna. Förövaren kan i samspelet med andra och inför sig själva använda redovisande tekniker som neutraliserar moraliska fördömanden genom att förneka eget ansvar för det inträffade, förneka att någon kommit till skada, hävda att handlingarna var nödvändiga med hänsyn till omständigheterna, definiera normbrottet som ett undantag från ens allmänt goda strävanden etc. (Tomita 1990, jfr Sykes \& Matza 1957). Det är troligt att den som utvecklar det kliniska perspektivets har en särskild förståelse för vissa typer av ursäkter och rättfärdiganden och en särskild obenägenhet att acceptera andra. I Hydle \& Johns exempel elimineras den vuxne sonens status som förövare av övergrepp efter bedömningen att han drivits av omsorgs- och pliktkänslor (rättfärdigande) och inte erhållit rimligt stöd av vårdsystemet (ursäkt). Accepterandet av dessa omständigheter är perspektivberoende och betoningen av dem väcker sannolikt särskild förståelse bland experter som själva har erfarenhet av det svåra vårdarbetet. I en studie av kanadensiska socialarbetare visar Poirier (1992) hur professionella normer snarare än lagstiftning influerade valet att intervenera i fall av övergrepp mot äldre i hemmet. Det har visat sig att exempelvis socialarbetare modellerar sin förståelse av övergrepp mot äldre på erfarenhet av övergrepp mot barn, med påföljd att ekonomiska övergrepp - finansiell exploatering och stöld - förblivit outredda. Sådana övergrepp har inte varit aktuella i den vårdprofessionella konstruktionen av övergrepp mot barn, men för äldre utgör de ensamt eller i kombination med andra övergrepp en central del av fenomenet (Brogden \& Nijhar 2000).

Risken är kort och gott att förövare och kliniker samspelar i en konstruktion av övergrepp mot äldre som ett uttryck för en ansträngd vårdrelation, alternativt patologi inom familjen. Typfall 2 kan därmed komma att döljas av typfall 1 och 3. Den typ av resonemang om egoistiska och rationella motiv som är centrala inom det kriminologiska sammanhanget - i domstolen exempelvis - tonas ned. Samma risk 
är uppenbar inom formell äldrevård, där resursbrist och systemfel ofta framställs som orsak till missförhållanden (Jönson 2002). I studier där vårdpersonal lämnat uppgifter om egna och kollegors övergrepp inom formell äldrevård har det visat sig att inte bara stress och arbetsbelastning anges som orsaker (SoS-Rapport 1994:1; Saveman et al. 1999; Goergen 2001). Vid sidan av sådana orsaker anges aggressiv läggning, olämplighet för vårdarbete, sociala och ekonomiska problem hos förövaren. I en analys av orsakerna till övergrepp på vårdinstitutioner för äldre har Collin Shaw (1998) identifierat två förövargrupper: de reaktiva och de sadistiska. Medan övergrepp från reaktiva förövare ofta utlöses av svåra omständigheter som aggression från vårdboende, begår de sadistiska förövarna upprepade och systematiska övergrepp som de därefter förnekar eller skyller på andra. Det finns alltså en problematisk tvåsidighet, där baksidan av det kliniska perspektivets nära förståelse för det svåra vårdarbetet är beredskapen att betrakta vissa legitimeringar och ursäkter som fullgoda redovisningar. De data jag samlat in för en pågående studie om vanvård styrker denna tolkning om benägenhet. Vårdprofessionella aktörer ursäktar och legitimerar ibland fall av påstådd vanvård och övergrepp som de inte har konkret kännedom om, med hänvisning till en slags initierad erfarenhetskunskap om stress och systemfel inom vården, som om dessa förhållanden per automatik vore tillämpliga i alla fall. Denna argumentation uttrycks som ett försvar mot syndabockstänkande och nedvärdering av vårdarbetet.

\section{Det feministiska perspektivet}

I denna artikel definierar jag ett feministiskt perspektiv på våld mot kvinnor som en ansats där våldet relateras till kulturella och sociala aspekter av manlig dominans/normalitet och kvinnlig underordning. Sådan forskning har både internationellt och i Sverige kommit att bli relativt omfattande och varierad (Se exempelvis Lundgren 1991; Hydén 1992; Holmberg 1993; Eliasson \& Forward 1992; SOU 1995:60).

Under lång tid betraktades hemmet inte som en typisk brottsplats utan snarast som den arena där familjen förmedlade normer som motverkade brottslighet. Feminismen har bidragit till en förändrad syn på familjen, med en påföljande kriminalisering av våld i hemmet. När det gäller övergrepp mot äldre menar Brogden \& Nijhar (2000) att ett dominerande patologi- och välfärdstänkande bidragit till att upprätthålla den klassiska uppdelningen mellan hem och offentliga miljöer. Rationalitet, maktutövning och strukturell ojämlikhet mellan könen har dolts genom fokuseringen av patologi hos offer och förövare. Internationellt har avsaknaden och relevansen av ett feministiskt perspektiv på övergrepp mot äldre (kvinnor) kommenterats av flera forskare (Whittaker 1997; Crichton et al. 1999). Det kan samtidigt noteras att kvinnorörelsen och feministiska forskare ägnat våld mot äldre kvinnor mycket ringa intresse. En genomgång av kvinnojourernas tidskrift Kvinnotryck visar att endast tre artiklar berörde våld mot äldre kvinnor under perioden 1991-2003. Som jämförelse har långt större intresse ägnats grupper som unga kvinnor och kvinnor av utomnor- 
disk härkomst. Samma frånvaro och fördelning är synlig i en omfattande bibliografi som sammanställts av Eliasson \& Forward (1991). Än mer anmärkningsvärt är att Eva Lundgrens (et al. 2001) stora kartläggning av svenska "kvinnors» våldserfarenhet inte omfattar kvinnor över 64 års ålder. Inom den omfattande feministiska forskningen om våld mot kvinnor har äldre kvinnor alltså varit påfallande frånvarande.

I min analys kommer jag att utgå från de två svenska rapporter som hittills använt ett feministiskt perspektiv för att förstå övergrepp mot äldre (kvinnor). I en rapport från Brottsoffermyndigheten har Hjelde Eriksson (2001) undersökt förekomsten och karaktären av "våld" mot äldre kvinnor och män i en svensk kommun. En senare rapport från Nationellt Råd för Kvinnofrid har refererat Erikssons resultat och ett liknande teoretiskt ramverk i en diskussion om äldre kvinnors utsatthet (Johansson 2002). Framför allt använder jag Brottsoffermyndighetens rapport för en diskussion om hur övergrepp mot äldre konstrueras inom det feministiska perspektivet.

Allmänt sett har feministiska forskare framställt sitt perspektiv som en utmanare till dominerande perspektiv och ordningar (Eliasson \& Forward 1992). Detta gäller också för Brottsoffermyndighetens rapport där Eriksson (2001, s. 57-58) skriver att genusaspekter, makt- och socioekonomiska förhållanden varit frånvarande i stora delar av den tidigare forskningen om övergrepp mot äldre. Att det ofta varit frågan om mäns våld mot kvinnor har dolts genom könsneutrala begrepp som "våld mot äldre", "familjevåld» och "partnervåld«. De två befintliga rapporterna har också valt en annorlunda vokabulär än den i Sverige vedertagna och ersatt begreppet övergrepp med våld. Samtidigt som innehållet i våldsbegreppet är mycket snarlikt förekommande definitioner av övergrepp (inkluderat fysiskt, psykiskt, sexuellt, ekonomiskt våld och försummelse) möjliggör det feministiska perspektivets betoning av kvinnors utsatthet och valdserfarenhet en inkludering av händelser i flera olika sammanhang. I en engelsk studie om rädsla för brott i offentlig miljö hänvisar Pain (1995; 1997) just till en sådan sammanlänkande våldserfarenhet när hon ifrågasätter etablerade föreställningar om att äldre kvinnor har en irrationell rädsla för brott $\mathrm{i}$ offentliga miljöer, med utgångspunkt i att de är minst brottsutsatta. Rädsla för våld $i$ offentliga miljöer kan enligt Pain vara en effekt av våldserfarenhet i hemmet. Som jämförelse tycks kliniskt/medicinskt orienterande handböcker och utbildningsmaterial, framför allt handla om upprepat våld i hemmiljön.

Det androcentriska samhället är ett viktigt kunskapsobjekt för feministisk forskning, i bemärkelsen att analysen avslöjar detta samhälle och dess genomslag i olika sammanhang. Både rapporten från Brottsoffermyndigheten (Eriksson 2001) och rapporten från Nationellt Råd för Kvinnofrid (Johansson 2002) refererar ingående till en i Norden mycket spridd modell, där mäns våld mot kvinnor förstås i termer av kontroll och normalisering (SOU 1995: 60; Lundgren 1991; et al. 2001). Den misshandlande mannen konstituerar sin maskulinitet och utövar kontroll genom våldshandlingar. Gradvis tvingar processen kvinnan att anta en självbild som underordnad och värdelös, med följd att mannens bestraffning ter sig 
naturlig. Poängen är att denna process kan hämta sin legitimitet i den existerande samhällsordningen, där kvinnor konstrueras som mindre värda. Våldets normaliseringsprocess är enligt Eriksson (2001) särskilt aktuell för äldre kvinnor som i många fall har mindre praktiska möjligheter att lämna ett förhållande på grund av en svag självständig ekonomi. Jämlikhet mellan könen är också en relativt ny fråga, vars genomslag antagligen är mindre bland äldre makar. Liknande uppgifter om särskild utsatthet tas upp i rapporten från Nationellt Råd för Kvinnofrid (Johansson 2002). Det feministiska perspektivet på övergrepp mot äldre har alltså synliggjort aspekter av socioekonomisk ojämlikhet och manlig dominans och kvinnlig underordning, genom att relatera problemet till en strukturella förhållanden. Med detta förs problemet ut från kliniken och fokuseringen av patologi ersätts med en fokusering av "normalitet».

I sin empiriska undersökning av våldserfarenhet efter 65 år bland personer $i$ åldrarna 65-80 år uppvisar rapporten från Brottsoffermyndigheten resultat som ligger i linje med flera genomgångar om övergrepp mot äldre (SoS-rapport 1994:1; Brogden \& Nijhar 2000; Crichton et al. 1999). Kvinnor hade i studien i högre grad än män blivit offer för "våld« och män utgjorde majoriteten av förövarna. ${ }^{2}$ I enlighet med den teorietiska ansatsen skilde sig också "våldets» karaktär. Endast kvinnor hade (med ett undantag) varit utsatta för sexuellt »våld«.

2 Våld definieras extensivt och tycks motsvara relativt vida definitioner av övergrepp, inkluderat fysiskt, psykiskt, sexuellt och ekonomiskt våld samt försummelse.
Kvinnor var i högre grad traumatiserade av "våld« före 65 års ålder, de var i högre grad utsatta för mer omfattande och upprepat våld och de kvinnor som rapporterade om viktimisering hade sämre hälsa relativt män som viktimiserats. Kvinnor hade också allmänt sett en mer utsatt social situation.

En kritik mot det feministiska perspektivet på övergrepp mot äldre kan sammanfattas som att övergrepp i allt för hög grad konstrueras som »kvinnomisshandel", (typfall 2 ovan, med karaktären mäns våld mot kvinnor) och att observationer som inte passar in i de teoretiska modellerna tonas ned och förklaras bort. Brottsoffermyndighetens rapport och spridning utgör ett exempel. Det huvudresultat om kvinnors särskilda utsatthet som under de senaste åren reproducerats i skrifter - exempelvis den från Nationellt Råd för Kvinnofrid - och lyfts fram på konferenser visar sig vid närmare betraktelse inte särskilt entydigt. Det var egentligen inte någon stor skillnad i rapporteringen av våldserfarenheten, 16 procent av kvinnorna rapporterade våldserfarenhet, mot 13 procent av männen.

I vissa fall framstod män också som mer utsatta än kvinnor och kvinnliga förövare stod för en icke obetydlig del av "våldet". Sådana resultat utgör anomalier som hotar det feministiska perspektivets trovärdighet om de inte förklaras. I Brottsoffermyndighetens rapport tolkas resultat som visar på förekomst av manliga offer och kvinnliga förövare med hjälp av den feministiska förklaringsmodellen. Resultatet att män i högre grad än kvinnor rapporterar utsatthet för hot och förödmjukelser relateras exempelvis till kvinnlig underordning. Från en underordnad position är kvinnor tving- 
ade att nyttja denna typ av indirekt "våld" (Eriksson 2001, s. 99). Kvinnors "våld» framstår därmed som en slags respons $i$ underläge, vilket ger handlingen ett slags rättfärdigande. Medan 15 procent av de män som avrapporterade försummelse angav en nuvarande partner som förövare, nämnde ingen kvinna maken som förövare av sådant "våld". Detta resultat relateras i rapporten till mäns högre förväntningar på omhändertagande, till ökad belastning som drabbar kvinnliga anhörigvårdare och möjligheten att kvinnor ger igen tidigare oförrätter när mannen försvagats. Poängen här är inte att ifrågasätta dessa förklaringars validitet, utan att peka på en viktig tendens hos det feministiska perspektivet: Medan mäns "våld" uttrycker överordning och maktutövning betraktas kvinnors "våld" som ett uttryck för externa faktorers inverkan. I dessa redovisningar konstrueras alltså kvinnligt förövarskap som ett slags undantag (jfr Griffin \& Aitken 1999). Den teoretiska modellen tillhandahåller också verktyg för tolkning av små skillnader i mäns och kvinnors våldsrapportering. I enlighet med normaliseringsprocessen är det troligt att kvinnor inte själva uppfattar våldets förekomst och alltså underrapporterar det. Män kommer å andra sidan att uppfatta kränkningar som hot mot sin maskulinitet och tidigare maktposition, och det är därför enligt rapporten troligt att de "överrapporterar" våld från nuvarande och tidigare partners (Eriksson 2001, s 7074). Samtidigt som dessa teoretiska resonemang tillför viktiga makt- och genusaspekter vid tolkning av viktimisering, introduceras en "obstruktionshypotes" som i praktiken gör teorin omöjlig att falsifiera.
Dessutom tillhandahålls resonemang som predisponerar bedömare att tolka enskilda fall av rapportering om utsatthet från män som obefogat gnäll. Återigen vill jag betona att jag inte ifrågasätter värdet eller rimligheten i analysen av våldets genusaspekter, utan enbart försöker visa på perspektivets tvåsidighet.

Genom den uppenbara förekomsten av kvinnliga förövare (exempelvis vuxna döttrar) och manliga offer kan övergrepp mot äldre (kvinnor) skapa en hel del oklarheter och oreda inom det feministiska perspektivet om mäns våld mot kvinnor. I det feministiska perspektivet relateras mäns våld mot kvinnor till manlig överordning och dominans (Holmberg 1993). Denna ordning är kulturellt och socialt befäst, både genom traditioner och i våra samtida partnerskap. I parrelationer har män i allmänhet högre lön, högre samhällsposition och större möjlighet att ta till våld genom en överlägsen fysisk styrka. Alla män är inte överlägsna sin partner vad gäller tillgången på »maktmedel " - men "potentialen finns där vilket påverkar både mannen och kvinnan (Eriksson 2001, s 71). Denna koppling till könsmakt och "normalförtryck» ter sig rimlig allmänt sett, men blir något mer dubiös när det gäller övergrepp mot äldre där svaghet och sårbarhet - hos äldre kvinnor och män tycks utgöra en central aspekt av själva fenomenet. Framtida studier av våld mot äldre kan tänkas uppvisa skillnader som styrker det feministiska perspektivet, exempelvis att våldets karaktär är artskild beroende av de inblandades kön. Oavsett detta kvarstår en besvärlighet, nämligen att den ovälkomna kategorin »utsatta män« tränger sig på som offer och därigenom grumlar kopp- 
lingen till "normalförtrycket». Detta visar sig bl.a. i Kvinnovåldskommissionens (SOU 1995:60) betänkande, där äldre män inkluderats i det avsnitt som handlar om äldre kvinnor som en särskilt sårbar kategori.

\section{Vad skiljer och vad förenar?}

I den här artikeln har jag diskuterat problemet våld och övergrepp mot äldre med utgångspunkt i två tolkande perspektiv. Dessa synliggör vissa aspekter av problemet, samtidigt som andra tenderar att komma i skymundan. Det feministiska perspektivets karaktäriseringar och resonemang tycks särskilt relevanta vid typfall 2 , dvs. vid det partnervåld som i realiteten ofta är mäns våld mot kvinnor. När det gäller delar av den internationella forskningen skulle man kunna säga att ett kliniskt/medicinskt perspektiv idealtypiskt baserat definitioner och resonemang på typfall 1 , där övergreppen har att göra med en vårdrelation. Denna karaktäristik stämmer emellertid illa i Norden. Som framgått har vårdforskare i Norden uppmärksammat både genusfrågor och i något fall också strukturella problem (Hydle 1989; Johns \& Hydle 1995). De har också tagit avstånd från tendenser att konstruera övergrepp mot kvinnor som övergrepp mot äldre (Hydle \& Johns 1993). De forskare som utvecklat ett feministiskt perspektiv på våld mot äldre i Sverige tycks i sin tur ha en förankring inom vården. I rapporterna från Brottsoffermyndigheten respektive Nationellt Råd för Kvinnofrid framgår det att rapportförfattarna själva är vårdprofessionella med klinisk erfarenhet. Nedan ska jag lyfta fram denna likhet i erfarenheter och utgångspunkter i en diskussion om hur de två perspektiven kan tänkas samverka i konstruktionen av övergrepp inom formell äldreomsorg.

Som nämnts tidigare finns det en "risk" att den som utvecklar det kliniska/medicinska perspektivet på övergrepp mot äldre har en särskilt mottaglighet för ursäkter och rättfärdiganden som hänvisar till ansträngda vårdrelationer. När det gäller formell äldreomsorg kunde det tänkas att det feministiska perspektivet skulle utveckla en parallell analys om hur personalen konstituerar sin yrkesidentitet eller åldersdominans genom en relation av överordning i förhållande till vårdtagare, enligt samma princip som män konstituerar maskulinitet i parrelationer. Genom att prata barnspråk med de gamla och behandla dem som ting, manifesteras makt samtidigt som en distans byggs upp till hotet om egen skröplighet och vårdberoende (Hockey \& James 1993). Ett kulturellt och individuellt förakt för svaghet och beroende kunde ses som drivkraften i en sådan modell (Tornstam 2001). På vårdboenden kunde övergrepp och vanvård därmed ses som uttryck för institutionaliseringens och eller ålderismens normaliseringsprocess. Brottsoffermyndighetens rapport (Eriksson 2001, s 64-67) innehåller en diskussion om maktförhållanden och avhumanisering av äldre kvinnor i vården, men identifierar samtidigt den i huvudsak kvinnliga personalen som offer, vid sidan av de utsatta vårdtagarna. Personalen är lågutbildad, har låg lön, saknar inflytande och befinner sig långt ner i samhällets hierarki. Återigen framstår våldet som orsakat av externa krafter. Ännu tydligare uttrycks resonemanget i rapporten från Nationellt Råd för 
Kvinnofrid. När författaren - som själv har lång erfarenhet av arbete inom äldrevård kommenterar våld och övergrepp på institutioner framstår "förövare» bland personalen på ett kategoriskt sätt som offer för systemfel:

"Ibland står samhället som förövare. När antalet timmar för beviljad hemtjänst minskar och personalen inom vård och omsorg drabbas av neddragningar sä ökar riskerna för våld och övergrepp. Detta gäller t ex vid ensamarbete nattetid på de kommunala boendena och vid nedläggningar av sjukhusens vairdavdelningar. Det är de äldre kvinnorna som drabbas extra hårt. Alltför tungt vårdansvar, stress, förtvivlan, trötthet och utbrändhet hos personalen kan troligtvis utlösa övergrepp mot äldre. När vårdpersonal utgör förövare bottnar det troligtvis $i$ brist på kunskap, vägledning och erfarenhet, men också $i$ en alltför låg bemanning på institutionerna. "(Johansson 2002, s 18).

Griffin \& Aitken (1999, s. 35) menar att feministiska forskares intresse för omsorgsarbete som en kvinnlig verksamhet resulterat $\mathrm{i}$ en tendens att identifiera vårdarens svårigheter och se sig själva som potentiella vårdare, snarare än vårdtagare. Det kan alltså tänkas att båda perspektivens företrädare är särskilt benägna att identifiera sig med förövarens svåra situation i de fall övergreppen äger rum i en vårdsituation.

Det är viktigt att återigen betona tvåsidigheten i denna problemkonstruktion. Perspektiven motverkar ett förenklat syndabockstänkande. Vårdarbetets nedvärderade och svåra karaktär synliggörs. Det blir möjligt att relatera övergrepp och vanvård till konflikter och våldsamheter från vårdtagare, samt till personalbrist, systemfel och förhållanden av strukturell karaktär. Samtidigt öppnas flyktvägar till legitimitet för personer som begår övergrepp för att de finner glädje i att utöva makt, inte betraktar offret som en människa, ser möjligheter att gynna sig själva, försöker skapa en bekväm arbetssituation med tuktade vårdtagare etc. Här kan man alltså tänka sig att förekomsten av fungerande moraliska flyktvägar eliminerar omgivningens sanktioner vid normbrott och därmed ökar sannolikheten för nya övergrepp (Tomita 1990). En praktisk illustration till problematiken återfinns i Ulla Melin Emilssons (1998, s 244) studie av samspelet mellan dementa och vårdpersonal på gruppboenden. Melin Emilsson genomförde deltagande observationer och noterade då hon anlände vid ett tillfälle att en boende som vanligtvis vandrade omkring satt fastbunden i rullstolen.

"Jag frågar det andra vårdbiträdet om den gamla damen blivit sämre eftersom hon sitter fastbunden. Gudrun som fortfarande är $i$ tvättstugan hör detta och kommer ut $i$ köket. Hon säger att den dementa har gått så mycket innan idag så de satte fast henne för att fä undan lite här."

Här ifrågasatte Melin Emilsson ett förhållande och erhöll då en redovisning från Gudrun. Fastbindandet av den gamla kvinnan blev genom redovisningen knappast något exempel på god vård, men var det ett övergrepp? Och vem var i så fall förövaren? Om personalen var så pressad av olika arbetsuppgifter att de tvingas 
binda fast vandrande vårdtagare för att de inte ska falla och skada sig själva, måste då inte handlingen ses i ljuset av den goda intentionen (rättfärdigande). Och var det inte samhället och vårdsystemet som var förövaren, som tvingade personalen att vidta handlingar av denna karaktär (ursäkt)? Gudruns förklaring anspelade på resonemang som är bekanta i debatter om äldreomsorg. Som deltagande observatör märkte Melin Emilsson emellertid att vårdbiträdet Gudrun smusslade med något och kunde till sist konstatera: "Jag känner igen en väska och en kasse som stod i tvättstugan och jag förstår att Gudrun har tvättat sin egen tvätt." I detta exempel var alltså vittnet närvarande under en längre tid på platsen och fick därmed information som visade att Gudruns handling var moraliskt illegitim, trots att hennes redovisning inte indikerade detta. Gudrun hade blivit vräkt från sin bostad, visade det sig och därför använde hon äldreboendet som privat tvättstuga. Konsekvensen blev att åtminstone en av de boende låstes fast. Så länge (och möjligen även efter att) ett egoistiskt motiv inte var synligt anknöt Gudruns redovisning om att "få undan" till olika resonemang som är förankrade i både det kliniska/medicinska och det feministiska perspektivet och det är därför inte otroligt att aktörer som utvecklar perspektiven skulle vara särskilt benägna att betrakta Gudrun som ett slags offer för arbetssituationen och möjligen för den samhälleliga nedvärderingen av kvinnor överlag.

\section{Perspektivens genomslag}

Hur kan man tänka sig att de två perspek- tivens problemversioner kommer att slå igenom framöver? En användbar idé om att problems samhälleliga genomslag beror på hur väl de skapar moralisk klarhet, återfinns i den norske kriminologen Nils Christies (1986) diskussion om ideala offer. Ett idealt offer dramatiserar enligt Christie det godas kamp mot det onda. Offret är idealtypiskt en sårbar person som utför ett legitimt ärende. Förövaren är stor, stark och kommer långt bortifrån. Mäns våld mot kvinnor i familjen har enligt Christie en grumligare karaktär och försök till kriminalisering möter motstånd från alla dem som betraktar fenomenet som en slags urartade bråk. Just dessa resonemang återfinns i Elisabeth Baumanns (1989) analys av den amerikanska debatten om övergrepp mot äldre. Baumann menar att övergrepp mot äldre framför allt kom att beskrivas som ett fall där en anhörig sviktade i sin omsorg mot en äldre person, eftersom denna problemkonstruktion hade en likhet till förälderns svek av förtroende vid övergrepp mot barn. Det blev möjligt att ta avstånd från den betrodde men svekfulle förövaren. Samtidigt doldes de moraliskt grumligare övergrepp som hade karaktären av kvinnomisshandel. Om detta tänkande appliceras på de två perspektiv jag diskuterat, är det $\mathrm{i}$ vart fall möjligt att spekulera om framtida genomslag. Detta ska jag göra genom två viktiga reservationer.

En första reservation rör idén om att en tydlig moralisk kamp mellan gott och ont ger ett kraftigt genomslag för en problemdefinition. Christies analys verkar i första hand avse massmedier, vissa myndigheter och organisationer, samt någon slags folkliga uppfattningar (Jönson \& Åkerström 2004). 
Inom den vårdprofessionella arenan tycks däremot demoniseringar av förövaren inte passa in alls. Istället har det kliniska/medicinska perspektivet betonat en komplexitet i relationerna - som just kräver den typ av kvalificerade bedömningar som professionella aktörer kan tillhandahålla. Utanför den vårdprofessionella arenan har genomslaget för ett kliniskt/medicinskt perspektiv varit svagare. Helt i enlighet med idén om moralisk klarhet har övergrepp mot äldre i hemmet sällan lyfts fram i massmedierna (Jönson 2002). Som jämförelse har vanvård inom formell äldreomsorg ägnats stor massmedial uppmärksamhet, och innehållit just fördömanden mot vårdpersonalens svek av förtroende. Ilskan har också riktats mot politiker, som i debatten framställts som ideala förövare i förhållande till de svaga åldringarna.

En andra reservation rör genomslaget för våld mot kvinnor inom familjen. Mäns våld mot kvinnor har nämligen enligt min mening fått status som uppburet samhällsproblem i Sverige. Här är det antagligen frågan om en samhällsförändring sedan 1980-talet, då Christie formulerade sin idé. Feminismen har fört en framgångsrik kamp i Sverige under de senaste årtiondena, åtminstone inom arenor som politik, forskning och hos statsmakterna. Följer man idén om moralisk klarhet blir det då möjligt att dra slutsatsen att kvinnorörelsen och det feministiska perspektivet har lyckats i sin strävan efter att skapa moralisk klarhet i fallet mäns våld mot kvinnor (Jönson \& Åkerström 2004). Denna klarhet har skapats genom resonemang som syn- liggör en ideal relation mellan offer och förövare, där feminister framgångsrikt introducerat begrepp som våldets "normaliseringsprocess» och manliga "härskartekniker«. Även om tänkandet knappast omfattas av "gemene man" har perspektivet fått ett genomslag inom statligt utredande (SOU 1995:60), hos instanser som brottsoffermyndigheten och brottsofferjourerna, samt inom en av de stora pensionärsorganisationerna (SPF) vars ordförande varit delaktig i Nationellt Råd för Kvinnofrid. Det feministiska perspektivets moraliska klarhet har alltså bidragit till att stärka äldre status som brottsoffer, och därmed har åtminstone vokabulären om övergrepp (våld) mot äldre blivit mer kriminaliserande.

Med tanke på hur mäns våld mot kvinnor slagit igenom som samhällsproblem, kan det feministiska perspektivet på övergrepp mot äldre förväntas få en fortsatt spridning, framför allt inom etablerade infrastrukturer för omhändertagande av brottsoffer - kvinnojourer och brottsofferjourer, samt inom med dessa närstående organisationer och myndigheter. Det är också tänkbart att denna moraliskt tydliga problemversion skulle kunna ges särskild uppmärksamhet i massmedier, kanske med våld mot unga och invandrade kvinnor som förebild. Förhoppningsvis innebär den eventuella framgången för idealtypen mäns våld mot äldre kvinnor inte att den kunskap om manliga offer, kvinnliga förövare och ömsesidigt våld som producerats inom det kliniska/medicinska perspektivet helt sopas bort. 


\section{Referenser}

Andersson, Lars (1997) Ålderism. Stereotypa föreställningar eller diskriminering som utgår frän en människas ålder. Rapport 1997:14, Stiftelsen Äldrecentrum, Stockholm.

Ansello, Edward F. (1996) "Causes and Theories", i Baumhover, L. A. \& Beall, C. (red.) Abuse, Neglect and Exploitation of Older Persons. Strategies for Assessment and Intervention, Baltimore: Health Professions Press, s. 9-29.

Baumann, E. A. 1989. "Research Rhetoric and the Social Construction of Elder Abuse." In Best, J. (Ed.). Images of Issues: Typifying Contemporary Social Problems, pp. 55-74. New York: Aldine de Gruyter.

Baumhover, Lorin A. \& Beall, S. Colleen (red.) (1996) Abuse, Neglect and Exploitation of Older Persons. Strategies for Assessment and Intervention, Baltimore: Health Professions Press.

Billig, Michael (1996) Arguing and thinking: A rhetorical approach to social psychology, (2 uppl.). Cambridge: Cambridge University Press.

Brogden, M. \& Nijhar, P. (2000) Crime, Abuse and the Elderly, Collompton: Willan Publishing.

Callahan, James J. (1988) „Elder Abuse: Some Questions for Policymakers." The Gerontologist 28, 4, s. 453-458.

Christie, Nils (1986) „The Ideal Victim», i Fattah, Ezzat A. (red.) From Crime Policy to Victim Policy. London: McMillan, s. 17-30.

Crichton, Susan J., Bond, John B., Harvey, Carol D. H., Ristock, Janice (1999) „Elder Abuse: Feminist and Ageist Perspectives", Journal of Elder Abuse \& Neglect, 10, 3/4, s. 115-130.

Collin Shaw, Mary M. (1998) „Nursing Home Resident Abuse by Staff: Exploring the Dynamics", Journal of Elder Abuse \& Neglect, 9, 4, s. 1-21.

Eastman, Mervin (1999) "Elder abuse and professional intervention: a social welfare model?", i Eastman, M. \& Slater, P. (Eds.) Elder Abuse: Critical Issues in Policy and Practice, s. 89-102. London: Age Concern.

Eliasson, M. \& Forward, S. 1992. Kvinnomisshandel-en indexerad bibliografi, Centre for Feminist Research, Uppsala University.
Eliasson, Rosmari (1995) Forskningsetik och perspektivval, Lund: Studentlitteratur.

Eriksson, Hjelde (2001) Våld mot äldre kvinnor och män—en omfångsstudie, Umeå: Brottsoffermyndigheten.

Griffin, G. \& Aitken, L. (1999) „Visibility Blues: Gender Issues in Elder Abuse in Institutional Settings", Journal of Elder Abuse \& Neglect 10, $1-2$, s. 29-42.

Goergen, Thomas (2001) "Stress, Conflict, Elder Abuse and Neglect in German Nursing Homes: A Pilot Study Among Professional Caregivers", Journal of Elder Abuse \& Neglect, 13, 1, s. 1-26.

Hockey, J. \& James, A. (1993) Growing Up and Growing Old - Ageing and Dependency in the Life Cours, London: Sage.

Holmberg, Carin (1993) Det kallas kärlek. En socialpsykologisk studie om kvinnors underordning och mäns överordning bland unga jämställda par. Göteborg: Anamma förlag.

Hudson, Margaret F. (1991) „Elder Mistreatment: A Taxonomy with Definitions by Delphi", Journal of Elder Abuse \& Neglect, 3, 2, s. 1-20.

Hugman, Richard (1995) »The Implication of the Term Elder Abuse for Problem Definition and Response in Health and Social Welfare." Journal of Social Policy 24, 4, s. 43-507.

Hydén, Margareta (1992) Woman battering as marital act. The construction of a violent marriage. Stockholm studies in social work: 7. Stockholm: Stockholms universitet.

Hydle, Ida \& Johns, Sigurd (1993) Övergrepp mot äldre-stängda dörrar och knutna nävar: Om misshandel i hemmet, Lund: Studentlitteratur.

Hydle, Ida (1989) „Gamla kvinnor och övergrepp i hemmet", i Kvinnomisshandel, JÄMFO-rapport. Stockholm: Jämfo, 1989.

Johansson, B. (2002) Han var väl inte alltid så snäll, Stockholm: Nationellt Råd för Kvinnofrid.

Johns, Sigurd \& Hydle, Ida (1995) „Norway: Weakness in Welfare." Journal of Elder Abuse \& Neglect 6, 3/4, s. 139-156.

Jönson, Håkan (2002) Idealt problem med förhinder. En studie av massmediers rapportering om 
brott mot äldre. Rapport 2002:2, Network for Research in Criminology and Deviant Behaviour at Lund University. Lunds universitet.

Jönson, Håkan \& Åkerström, Malin (2004) "Äldre som ideala brottsoffer?", i Blomberg, H., Kroll, C., Lundström, T. \& Swärd, H. (red.) Sociala problem och socialpolitik $i$ massmedier, Lund: Studentlitteratur, s. 93-125.

Kivelä, S. A. (1995) "Elder Abuse in Finland", Journal of Elder Abuse \& Neglect 6, 3/4, s. 31-44.

Kosberg, Jordan I. \& Nahmiash, Daphne (1996) "Characteristics of Victims and Perpetrators and Mileus of Abuse and Neglect", i Baumhover, L. A. \& Beall, C. (red.) Abuse, Neglect and Exploitation of Older Persons. Strategies for Assessment and Intervention, Baltimore: Health Professions Press, s. 31-49.

Lo-Johansson (1952) Ålderdoms-Sverige. En stridsskrift av Ivar Lo-Johansson, Stockholm: Albert Bonniers förlag.

Lundgren, Eva (1991) Våldets normaliseringsprocess. Två parter - två strategier. Stockholm: Riksorganisationen för kvinnojourer i Sverige, ROKS.

Lundgren, Eva, Heimer, Gun, Westerstrand, Jenny, Kalliokoski, Anne-Marie (2001) Slagen dam: Mäns våld mot kvinnor i jämställda Sverigeen omfängsundersökning, Umeå: Brottsoffermyndigheten.

Melin Emilsson, Ulla (1998) Vardag i olika världar. Om dementa och vårdbiträden på tre gruppboenden. Lund: Arkiv.

McCreadie, Claudine (1993) „From Granny Battering to Elder Abuse: A critique of U.K. Writing, 1975-1992", Journal of Elder Abuse \& Neglect, Vol. 5, 2, s. 7-25.

Mills, C. Wright (1940) "Situated Actions and Vocabularies of Motive", American Sociological Review, 6, s. 904-913.

Odén, Birgitta (1991) „Relationer mellan generationerna. Rättsläget 1300-1900«, i Maktpolitik och husfrid. Studier i internationell och svensk historia tillägnade Göran Rystad. Lund: Lund University Press, s 85-116.

Pain, Rachel H. (1995) „Elderly Women and Fear of Violent Crime: The Least likely Victims? British
Journal of Criminology. 35, 4, s. 584-598.

Pain, Rachel H. (1997) "Old Age' and Ageism in Urban Research: The Case of Fear of Crime." International Journal of Urban and Regional Research. 21, 1, s. 116-128.

Perttu, S. (1996) "Abuse of the Elderly: Services Provided for Victims in a Finnish Nursing Home-1992-1993", Journal of Elder Abuse \& Neglect 8, 2, s. 23-31.

Poirier, Donald (1992) "The Power of Social Workers in the Creation and Application of Elder Protection Statutory Norms in New Brunswick and Nova Scotia", Journal of Elder Abuse \& Neglect, 4, 1/2, s. 113-133.

Pritchard, Jacki (1993) "Dispelling Some Myths", Journal of Elder Abuse \& Neglect, 5, 2, s. 27-36.

Saveman, Britt-Inger (1994) Formal carers in health care and the social services witnessing abuse of the elderly in their homes, Umeå: Department of Advanced Nursing, Umeå University.

Saveman, Britt-Inger \& Hallberg, Ingalill R. (1994) "The Attitudes of Formal Carers and their Suggested Interventions in Hypothetical Situations Involving Abuse of the Elderly", i Saveman, B.-I. Formal carers in health care and the social services witnessing abuse of the elderly in their homes, Umeå: Department of Advanced Nursing, Umeå University, s. 171-196.

Saveman, Britt-Inger, Berisson, Ann-Katrin, Eliasson, Pia, Lindstedt, Anna-Lena \& Pettersson, Lise-Lotte (1998) Övergrepp mot äldre $i$ hemmet, Temahöfte, Kalmar Läns Vårdhögskola.

Saveman, Britt-Inger, Åström, Sture, Bucht, Gösta \& Norberg, Astrid (1999) Elder Abuse in Residential Settings in Sweden, Journal of Elder Abuse \& Neglect, 10, 1/2, s. 43-60.

Scott, Marvin B. \& Lyman, Stanford M. 1968. "Accounts." American Sociological Review, 33, pp. 46-62.

Slater, Phil (1999) „Elder abuse as harm to older adults: The relevance of age ", i Eastman, M. \& Slater, P. (red.) Elder Abuse: Critical Issues in Policy and Practice, pp. 38-54. London: Age Concern.

SoS-Rapport 1994:1, Övergrepp mot äldre $i$

Håkan Jönson: Övergrepp mot äldre i två perspektiv. 
hemmet-Ser vi toppen på ett isberg? Stockholm: Socialstyrelsen.

SOU 1995:60. Kvinnofrid: Slutbetänkande av kvinnovåldskommissionen. Stockholm.

Sykes G. \& Matza, D. (1957) »Techniques of Neutralization. A Theory of Delinquency", American Sociological Review, 22, s. 664-670.

Tomita, Susan K. (1990) »The Denial of Elder Mistreatment by Victims and Abusers: The Application of Neutralization Theory", Violence and Victims, 5, 3, s 171- 184.

Tornstam, Lars (1989) "Abuse in Denmark and Sweden: Results from a Population Study.» Jour- nal of Elder Abuse \& Neglect 1, 1, s. 35-44.

Tornstam, Lars (2001) Alldrandets socialpsykologi, Stockholm: Prisma.

Whittaker, Teri (1997) »Rethinking Elder Abuse: Towards an Age and Gender Integrated Theory of Elder Abuse", i Decalmer, P. \& Glendenning, F. (red.) The Mistreatment of Elderly People (2 uppl.), s. 116-128. London: Sage.

Wolf, Rosalie S. (1996) "Foreword", i Baumhover, L. A. \& Beall, C. (red.) Abuse, Neglect and Exploitation of Older Persons. Strategies for Assessment and Intervention, Baltimore: Health Professions Press, s. xi-xiii.

\section{Summary \\ Elder abuse from two perspectives}

In this article I describe and critically analyse two perspectives that have made important contributions to the understanding of elder abuse in Scandinavia. A medical/clinical perspective has related abuse to causes and solutions that typically appear in clinical practices. This perspective has stressed the complex aspects of the problem. Writings have aimed at educating health care staff and social workers who meet abused elders. A feminist perspective has related elder abuse to gender inequalities and highlighted the vulnerability of elderly women. This perspective typically constructs the problem as a case of men's battering of women. The aim of this article is to show how the two perspectives tend to make some aspects and versions of abuse particularly visible, while other aspects are de-emphasized or made invisible. It is concluded that both perspectives provide valuable reasoning regarding the character and causes of the problem and possible solutions to it. In doing this they also provide accounts that perpetrators may use when excusing or justifying their behaviour. This two-sided phenomenon is especially evident when abuse occurs in a situation that involves caring. 